\title{
EVALUASI SISTEM PENGENDALIAN INTERN PENJUALAN KREDIT BERDASARKAN KERANGKA COSO PADA PT BUSSAN AUTO FINANCE MAKASSAR 2
}

\author{
Shofiana Syam \\ (Politeknik Informatika Nasional) \\ shofianasyam83@gmail.com
}

\begin{abstract}
ABSTRAK
Penelitian ini bertujuan untuk mengetahui apakah sistem pengendalian intern penjualan kredit telah sesuai dengan kerangka COSO.Penelitian ini dilakukan di PT Bussan Auto Finance Makassar 2 mulai bulan April sampai Mei tahun 2020. Desain penelitian yang digunakan adalah jenis penelitian deskriptif kualitatif. Metode analisis yang digunakan adalah kerangka COSO sistem pengendalian intern.Berdasarkan penelitian ini yang peneliti lakukan dapat disimpulkan bahwa sistem pengendalian intern penjualan kredit yang diterapkan di PT Bussan Auto Finance Makassar 2 sudah sesuai dengan kerangka sistem pengendalian intern COSO.
\end{abstract}

Keywords:: Pengendalian intern, penjualan kredit.

\section{PENDAHULUAN}

\section{Latar Belakang}

Di era modern seperti saat ini setiap perusahaan dituntut untuk dapat mengikuti perkembangan dan perubahan. Maka perusahaan berupaya untuk melakukan perbaikan-perbaikan yaitu dengan menghasilkan produk yang berkualitas sehingga banyak diminati konsumen, menciptakan sumber daya manusia yang terlatih dan berpotensi, sehingga perusahaan tersebut dapat bertahan dan dapat bersaing dengan perusahaan lainnya.

Sistem pengendalian intern mencakup struktur organisasi dan seluruh metode serta prosedur yang terkoordinir yang diterapkan oleh perusahaan untuk mengamankan hartanya, mengecek ketelitian, dan kepercayaan terhadap data akuntansi, mendorong kegiatan agar efisien dan mendorong 
ditaatinya kebijakan perusahaan. Semakin efektif sistem pengendalian intern pada suatu perusahaan maka laporan keuangan yang dihasilkan semakin dapat dipercaya dan sebaliknya semakin tidak efektif sistem pengendalian intern perusahaan itu maka akan semakin tidak dipercayainya laporan keuangan yang dihasilkan perusahaan tersebut. Penjualan kredit mengandung risiko besar bagi perusahaan yakni berupa kerugian yang dialami apabila debitur tidak melunasi kewajibanya. Sistem pengendalian yang ada dalam penjualan kredit akan sangat berperan dalammengurangi risiko tersebut.

Pembiayaan atau financing, yaitu pendanaan yang diberikan oleh suatu pihak kepada pihak lain untuk mendukung investasi yang telah direncanakan, baik dilakukan sendiri maupun lembaga. Dengan kata lain, pembiayaan adalah pendanaan yang dikeluarkan untuk mendukung investasi yang telah direncanakan. Pengendalian intern perusahaan merupakan suatu rencana organisasi dan metode bisnis yang digunakan untuk meningkatkan efektivitas dan efesiensi, menjaga aset, memberikan informasi yang akurat, mendorong mematuhi peraturan dan ketentuan manajemen yang telah diterapkan. Penulisan menggunakan Committee of Sponsoring Organization of Tradeway Commission (COSO) untuk mengetahui keefektifan pengendalian intern yang di terapkan pada PT Bussan Auto Finance Makassar 2 dan kesesuaian dengan komponen pengendalian intern menurut Committee of Sponsoring Organization of Tradeway Commission (COSO).

PT Bussan Auto Finance Makassar 2 merupakan perusahaan badan usaha milik swasta yang bergerak dalam bidang pembiayaan kendaraan sepeda motor dan pinjaman dana tunai, namun PT Bussan Auto Finance Makassar 2 dalam mengoptimalkan layanan terhadap para nasabahnya, perusahaan ini telah membuka kantor cabang atau perwakilan di beberapa tempat. Pada PT Bussan Auto Finance Makassar 2 sendiri terdapat kejadian mengenai penjualan kredit yang telah berlangsung lama, mengingat bahwa transaksi yang dilakukan adalah penjualan kredit tentu membuat perusahaan merasa perlu untuk menagih pihak yang bersangkutan yang nominalnya juga tidaklah sedikit. Maka dari itu, perlu dilakukan penagihan sebab pihak 
bersangkutan telah mengatakan akan melunasi piutang tersebut. Dengan adanya kejadian seperti ini, tentunya perlu dilakukan penanganan khusus untuk mengatasinya.

\section{TELAAH LITERATUR DAN PENGEMBANGAN HIPOTESIS}

\section{Landasan Teori}

\section{Evaluasi}

Menurut Stufflebeam, dkk dalam (Mariana,2020) Evaluasi adalah:"proses menggambarkan, mendapatkan, dan menyediakan informasi yang berguna untuk menilai alternatif keputusan".

\section{Sistem}

Menurut Azhar Susanto sistem merupakan:"Kumpulan/group dari sub sistem/bagian/komponen apapun baik fisik maupun non fisik yang saling berhubungan satu sama lain dan bekerja sama secara harmonis untuk mencapai satu tujuan tertentu."

\section{Pengendalian Intern}

Menurut COSO (Committee of Sponsoring Organization) (2013,hal:95) pengendalian intern adalah:

"suatu proses yang dipengaruhi oleh dewan direksi, manajemen dan karyawan yang dirancang untuk memberikan jaminan yang meyakinkan bahwa tujuan organisasi akan dapat dicapai melalui: efesiensi dan efektivitas operasi, penyajian laporan keuangan yang dapat dipercaya, ketaatan terhadap undang undang yang berlaku"

\section{Tujuan Pengendalian Intern}

Menurut Mulyadi (2010,hal:164) Tujuan pokok sistem pengendalian intern adalah:

a) Menjaga kekayaan organisasi

b) Mengecek ketelitian dan keandalan data akuntansi

c) Mendorong efesiensi

d) Mendorong dipatuhinya kebijakan manajemen

\section{Penjualan Kredit}

Penjualan kredit (Mulyadi, 2016:160) adalah: "Transaksi yang terjadi atas barang atau jasa, baik secara kredit maupun tunai. Dalam transaksi 
penjualan kredit, jika order dari pelanggan telah dipenuhi dengan pengiriman barang atau jasa,untuk jangka waktu tertentu perusahaan memiliki piutang kepada pelanggannya. Kegiatan penjualan secara kredit ini ditangani oleh perusahaan melalui sistem penjualan kredit."

\section{Sistem Pengendalian Internal Berdasarkan Kerangka COSO}

Tabel 2.1 Sistem Pengendalian Internal Berdasarkan Kerangka COSO

\begin{tabular}{|c|c|c|}
\hline No & Aspek & Indikator \\
\hline 1 & Lingkungan Pengendalian & $\begin{array}{l}\text { a.Nilai Integritas dan etika } \\
\text { b.Terbentuknya struktur organsasi } \\
\text { perusahaan secara rinci. } \\
\text { c.Dewan direksi dan Komite Audit } \\
\text { d.Komitmen terhadap Kompetensi } \\
\text { e.Adanya Pendelegasian wewenang dan } \\
\text { Tanggung jawab karyawan. } \\
\text { f.Filosofi dan gaya operasi } \\
\text { g.Kebijakan dan praktek sumber daya } \\
\text { manusia }\end{array}$ \\
\hline 2 & Aktivitas Pengendalian & $\begin{array}{l}\text { a. aktivitas persetujuan kerja } \\
\text { b.aktivitas pemisahan tugas } \\
\text { c.aktivitas tanggung jawab dan } \\
\text { kewenangan } \\
\text { d.aktivitas pendokumentasian } \\
\text { e.rekonsiliasi }\end{array}$ \\
\hline 3 & Penilaian Resiko & $\begin{array}{l}\text { Melibatkan proses yang dinamis dan } \\
\text { berulang (iterative) untuk } \\
\text { mengidentifikasi dan menganalisis risiko } \\
\text { terkait pencapaian tujuan, yang meliputi } \\
\text { Character, Capital, Capacity, Condition } \\
\text { dan Collateral. }\end{array}$ \\
\hline 4 & Pemantauan atau Monitoring & $\begin{array}{l}\text { Adanya keterlibatan manajemen dalam } \\
\text { memantau langsung pelaksanaan sistem } \\
\text { pengendalian internal prosedur } \\
\text { penerimaan kas secara berkala dan } \\
\text { kontinyu kemudian melakukan evaluasi } \\
\text { berdasarkan pemantauan dan } \\
\text { monitoring(pertimbangan) }\end{array}$ \\
\hline 5 & Informasi dan Komunikasi & $\begin{array}{l}\text { Manajemen harus memperoleh, } \\
\text { menghasilkan dan menggunakan } \\
\text { informasi yang relevan dan berkualitas, } \\
\text { baik yang berasal dari sumber internal } \\
\text { maupun eksternal. Komunikasi yaitu } \\
\text { proses iteratif dan berkelanjutan untuk } \\
\text { memperoleh,membagikan, } \\
\text { menyediakan informasi. }\end{array}$ \\
\hline
\end{tabular}




\section{METODELOGI PENELITIAN}

\section{Lokasi dan Waktu Penelitian}

Penelitian ini dilakukan pada PT Bussan Auto Finance Cabang Makassar 2 Jl.Perintis Kemerdekaan, No. 6-7, Tamalanrea, Makassar, Sulawesi Selatan 90245.Penelitian ini dilaksanakan selama 2 (dua) bulan Mulai April sampai Mei 2020.

\section{Desain Penelitian}

Penelitian ini menggunakan desain penelitian deskriptif kualitatif dengan pendekatan kualitatif dengan Evaluasi sistem pengendalian intern penjualan kredit berdasarkan kerangka coso.

\section{Metode Analisis Data}

Teknik analisis data dengan menggunakan pendekatan deskriptif komparatif yaitu membandingkan sistem pengendalian intern penjualan kredit berdasarkan perusahaan dan kerangka coso yang meliputi :
a) lingkungan pengendalian,
b) aktivitas pengendalian,
c) penilaian resiko,
d) pemantauan dan monitoring,
e) informasi dan komunikasi.

\section{HASIL PENELITIAN DAN PEMBAHASAN}

\section{Hasil Penelitian}

Dalam Penelitian ini, dilakukan penelitian terhadap sistem pengendalian intern pejualan kredit berdasarkan kerangka coso Pada PT Bussan Auto Finance Makassar 2. Adapun hasil penelitian penulis yang diperoleh, sebagai berikut :

\section{a) Lingkungan Pengendalian}

1) Nilai integritas dan etika

Pada pelaksanaan, PT Bussan Auto Finance Makassar 2 dalam melakukan pengendalian intern penjualan kredit berdasarkan kerangka coso memiliki visi misi yaitu, Visi menjadi 
perusahaan pembiayaan terkemuka dan terpercaya bagi pelanggan, mitra usaha dan masyarakat dan Misi memberikan layanan solusi keuangan terbaik untuk meningkatkan kesejahteraan hidup masyarakat. Pada perusahaan ini, biasanya melakukan diskusi seperti meeting dan briefing untuk menentukan pihak yang bersangkutan dapat diberikan penjualan secara kredit atau di tolak ataupun biasanya mengetahui kinerja setiap harinya untuk karyawan yang kerja di bagian lapangan. Biasanya diskusi dilakukan setiap ada pelanggan baru yang hendak melakukan pembelian secara kredit.

Dalam kegiatan tersebut, di setiap bidang pada PT Bussan Auto Finance Makassar 2 memberikan laporan hasil pencapaiannya setiap awal bulan sehingga akan diketahui kinerja per bidang atau divisi, di samping itu setiap karyawan memberikan tanggapan, saran atau masukan ke arah perbaikan, sedangkan head cabang bertugas untuk mengawasi dan memberikan arahan kepada karyawan per bidang agar semangat dan terus meningkatkan kinerjanya masing-masing. Seperti misalkan dalam pembayaran banyak konsumen yang menunggak, maka head cabang memerintahkan agar penagihan dilakukan oleh bagian penagihan ARO (collector) ke konsumen jika memungkinkan hingga pukul enam sore, selain itu untuk calon debitur memiliki syarat pegawai tetap dan tidak boleh kontrak rumah, memperlihatkan slip gaji bagi PNS dan karyawan swasta wajib memperlihatkan SITU/SIUP bagi wiraswasta.

Dalam membantu karyawan melaksanakan tugas-tugas, maka pihak PT Bussan Auto Finance Makassar 2 menyediakan untuk masing-masing chift up memiliki id dan password atau kata kunci untuk memasuki data/program di setiap masing-masing bidang. Tetapi kalaupun tiap-tiap bagian memiliki data atau program yang berbeda dengan yang lainnya maka data atau programnya pun saling berhubungan dan terintegrasi. Misalnya data-data 
konsumen yang di masukkan oleh data entry di bagian Pelayanan (CRO) akan masuk secara otomatis ke bagian Admin dan data pembayaran piutang yang dilakukan oleh bagian kasir. Untuk perubahan data atau perbaikan data yang telah diotorisasi hanya boleh dilakukan oleh chift up dan harus disetujui atau dilaporkan oleh Head Cabang.

2) Struktur organisasi

Dalam hal ini, PT Bussan Auto Finance Makassar 2 memiliki struktur organisasi yang digambarkan dalam bagan (halaman 48). Dari struktur organisasi tersebut, maka setiap orang dapat melihat dan mengetahui posisi di setiap bagian. Struktur organisasi yang digambarkan secara jelas, setiap orang dapat melihat tanggung jawab dan alur komunikasi pada setiap bagiannya. Selain itu menunjukkan bagian, seseorang juga dapat mengetahui tanggung jawab dan proses otorisasi serta pengawasan yang dijalankan setiap struktur organisasi tersebut.

3) Dewan direksi dan komite audit

Dewan direksi dan komite audit sangat berpengaruh bagi setiap organisasi. Dewan komisaris berwenang membentuk komite audit dan komite audit bertanggung jawab kepada dewan komisaris. Salah satu tugas utama komite audit adalah memberikan rekomendasi sehubungan dengan sistem pelaporan dan proses pengendalian internal.

Selain itu dengan adanya audit internal secara berkala pada PT Bussan Auto Finance yang dilaksanakan oleh satuan Divisi internal Audit dapat membantu pengawasan terhadap pengendalian internal penjualan kredit menjadi efektif dan untuk penanganan fraud atau pelanggaran semuanya ditanggung jawabkan oleh Divisi internal audit.

4) Komitmen terhadap kompetensi

Berdasarkan visi dari PT Bussan Auto Finance Makassar 2 yaitu Menjadi perusahaan pembiayaan termuka dan terpercaya 
bagi pelanggan, mitra usaha dan masyarakat. Hal ini, perusahaan membutuhkan karyawan-karyawan yang memiliki kemampuan masing-masing yang dibutuhkan perusahaan. Perusahaan ini menetapkan syarat tertentu untuk karyawan yang akan dipilih, sehingga setelah diterima menjadi karyawan dapat menjalankan pekerjaan dengan baik dan semakin mengarah ke profesional dalam bidang yang di berikan nantinya. Pimpinan Cabang menetapkan kebijakan dan praktik pelaksanaan kegiatan melalui SOP (Standard Operating Procedure). Setiap Pekerjaan harus sesuai dengan standar atau procedure yang di berikan/berlaku.

5) Pendelegasian Wewenang dan Tanggung Jawab

Pada PT Bussan Auto Finance Makassar 2 sudah melakukan pemisahan tugas dalam pengendalian intern penjualan kredit yaitu dengan adanya pemisahan tugas antara bagian keuangan, bagian admin, bagian marketing, bagian collection, dan bagian syana. Dengan adanya penjualan kredit disetujui oleh pihak yang berwenang, terdapat kebijakan pengiriman barang hanya jika dokumen pengiriman telah disetujui oleh pihak yang berwenang, terdapat kebijakan mengenai sanksi kepada karyawan atas tindakan tidak jujur, ilegal, dan tidak etis yaitu berupa teguran sampai pemutusan hubungan kerja. Selain itu, Kepala Cabang PT Bussan Auto Finance Makassar 2 mengevaluasi tekanan dan kendala melalui pembinaan (coaching) dan penyuluhan (conseling).

6) Filosofi dan Gaya Operasi

Filosofi dalam perusahaan adalah memberikan konstribusi secara signifikan bagi perwujudan masyarakat di mana semua orang di seluruh dunia dapat menjalani kehidupan yang berlimpah serta kekayaan materi dengan rasa terpenuhi dan kepuasan. Gaya operasi dalam perusahaan merupakan titik berat perusahaan akan berkembang.

7) Kebijakan dan Praktek Sumber Daya Manusia 
Kebijakan dan Praktek Sumber Daya Manusia di dasari pada suatu konsep bahwa setiap karyawan adalah manusia. Karyawan merupakan unsur yang penting dalam struktur pengendalian intern, dengan demikian PT Bussan Auto Finance Makassar 2 sangat berkepetingan memiliki karyawan yang kompeten dan jujur agar tercipta lingkungan pengendalian yang baik. Perusahaan ini perlu memiliki metode yang baik dalam menerima karyawan, mengembangkan kompensasi atas prestasi mereka.

\section{b) Aktivitas Pengendalian}

Aktivitas pengendalian terhadap penjualan kredit pada PT Bussan Auto Finance Makassar 2 di bagi ke dalam beberapa aktivitas, yang meliputi :

1) Aktivitas persetujuan kerja dilakukan oleh pihak pusat, dalam hal ini adalah Divisi Audit yang berada di Jakarta Pusat PT Bussan Auto Finance.

2) Aktivitas tanggung jawab dan kewenangan masing-masing bagian, mulai dari bagian keuangan yaitu Kasir yang menerima angusran konsumen dan merekap jumlah angsuran dari penjualan dan penagihan di setiap bagian dan bagian collcetion atau bagian penagihan tugasnya melakukan penagihan ke konsumen saat pembayaran sudah jatuh tempo.

3) Aktivitas pemisahan tugas oleh masing-masing bagian dan fungsi yang berhubungan dengan penjualan kredit. Antara lain (a) bagian keuangan terpisah dengan bagian penjualan (CMO), (b) bagian penjualan (CMO) terpisah dengan bagian Penagihan (ARO). Hal ini bertujuan untuk mengurangi penyimpangan, baik penyimpangan berupa kesalahan pencatatan maupun penyimpangan berupa kecurangan atau manipulasi data.

4) Aktivitas Pendokumentasian terhadap piutang oleh bagian penjualan adalah:

(a) Kuitansi penerimaan yang dikeluarkan oleh kasir menunjukkan berkurangnya jumlah piutang usaha. 
(b) Laporan kas harian yang dibuat oleh kasir merupakan dokumen pembantu penerimaan kas dari piutang usaha.

(c) From Persetujuan kredit yang sudah atau telah di otorisasi merupakan dokumen bertambahnya piutang usaha.

5) Rekonsiliasi, Kegiatan rekonsiliasi yang menyangkut piutang adalah:

(a) Mencocokan rekapitulasi penerimaan angsuran dari program sunfish dengan saldo piutang usaha di bagian keuangan.

(b) Melakukan report aging piutang harian dari program sunfish dengan saldo piutang usaha di bagian keuangan.

(c) Melakukan cross check antara rekapitulasi penerimaan angusran dari akuntansi dengan report aging piutang di dalam program secara berkala (harian atau mingguan).

\section{c) Penilaian Resiko}

Penilaian resiko merupakan hal yang penting bagi perusahaan, Setiap keputusan yang diambil oleh Kepala Cabang Pada PT Bussan Auto Finance Makassar 2 sudah dipertimbangkan resiko yang mungkin terjadi kedepannya. Adapun beberapa kemungkinan penilaian resiko, antara lain:

1) Character(Karakter)

Karakter adalah analisa atau penilaian terhadap karakter, kepribadian dan kematangan mental calon konsumen (CK), khususnya saat pengajuan kredit.

Dapat diperoleh dari: - Survey Lingkungan

- Survey Calon Konsumen(CK)

2) Capacity(Kapasitas)

Kapasitas adalah analisa atau penilaian terhadap kemampuan Calon Konsumen (CK) dalam membayar angsuran per bulannya. Dapat diperoleh dari: 1) Penghasilan CK, 2) Penghasilan Pasangan dan 3) Penghasilan Penjamin.

3) Capital(Kapital)

Kapital adalah analisa atau penilaian terhadap aset dan kekayaan 
yang dimiliki Calon Konsumen (CK). Dapat diperoleh dari: 1) Survey Lingkungan, 2) Memeriksa dokumen persyaratan kredit yang diserahkan CK, dan 3) Menilai aset dengan melihat barangbarang yang dimiliki

4) Condition(Kondisi)

Kondisi adalah menilai faktor-faktor yang dapat mempengaruhi konsumen dalam membayar angsuran atau menyelesaikan kewajiban.

Dapat diperoleh dari: 1) Umur CK, 2) Kondisi keluarga CK dan 3) Dokumen CK

5) Collateral(Kolateral)

Kolateral adalah menilai keamanan jaminan dari pinjaman CK.

Dapat diperoleh dari: 1) Siapa yang menggunakan unit, 2) atas nama BPKB, dan 3) Besarnya DP

\section{d) Pemantauan atau Monitoring}

Pada PT Bussan Auto Finance Makassar 2 telah menggariskan tanggungjawab kepada masing-masing bagian secara jelas. Kelancaran pembayaran piutang usaha menjadi tanggungjawab bagi tiap-tiap bagian yang membidangi piutang usaha, Karena antara bagian satu dengan bagian yang lainnya saling berkaitan. Misalkan bagian penjualan mengingatkan ke bagian penagihan untuk melakukan penagihan terhadap konsumen yang masa jatuh temponya sudah lewat. Bagian penagihan dituntut untuk bekerja yang maskimal agar mencegah terjadinya piutang tak tertagih. Kinerja yang dimiliki oleh masing-masing bagian selalu dipantau berdasarkan informasi dari report aging piutang periode sebelumnya, sehingga hasil pencapaian terhadap pengumpulan piutang usaha akan dilakukan evaluasi lebih lanjut oleh Kepala cabang untuk melihat atau menilai tingkat prestasi karyawan yang bersangkutan, dengan hal ini berkaitan dengan pemberian promosi dan insentif.

\section{e) Informasi dan Komunikasi}

Perusahaan ini biasanya mengadakan pertemuan rutin antara atasan 
dan kepala bagian atau karyawan dalam mengambil keputusan yang dimiliki oleh setiap karyawan. Dalam pengambilan informasi, biasanya bagian penagihan (ARO) pada perusahaan PT Bussan Auto Finance Cabang Makassar 2 akan memastikan apakah konsumen tersebut bisa melakukan pembayaran sesuai dengan kesepakatan yang telah dibuat. Tapi apabila konsumen tidak melakukan kesepakatan sesuai yang telah dijanjikan, biasanya bagian penagihan (ARO) mendatangi pelanggan di rumah yang bersangkutan. Adapun informasi dari setiap bagian yang membidangi penjualan kredit, diantaranya :

1) Informasi dari Surveryor mengenai kondisi calon debitur maupun debitur saat ini. Informasi ini bertujuan apakah calon debitur tersebut layak diberi kredit atau tidak dan dapat diperpanjang atau tidak.

2) Informasi dari CRO (Costumer Relasion Order) mengenai Konsumen yang $\mathrm{AO}$ maupun yang $\mathrm{RO}$. Informasi ini bertujuan untuk memberikan data keakuratan data konsumen yang ada di BAF sehingga bisa lebih meyakinkan pemberian kredit ke calon debitur.

3) Informasi dari APPI (asosiasi perusahaan pembiayaan indonesia) bertujuan apakah masih mempunyai tunggakan atau history pembayaran di perusahaan pembiayaan yang lain.

4) Data tentang riwayat pembayaran calon debitur kepada pembiayaan (akuntansi) lain. Informasi ini bertujuan untuk memastikan apakah si calon debitur belum pernah melakukan penunggakan pada pembiayaan lain selama periode pembayaran angsuran diperusahaan kami.

\section{Pembahasan}

Lingkungan pengendalian terhadap penjualan kredit pada PT Bussan Auto Finance Makassar 2 sudah berjalan dengan baik, dengan hal ini ditandai diadakannya perusahaan yang mencakup sikap para manajemen dan karyawan terhadap pentingnya pengendalian yang ada di organisasi tersebut diantaranya adalah Nilai Integritas dan etika, Struktur Organisasi, 
Dewan direksi dan komite audit, Komitmen terhadap kompetensi, Pendelegasian Wewenang dan Tanggung Jawab, Filosofi dan Gaya Operasi, Kebijakan dan praktek sumber daya manusia.

Aktivitas pengendalian ini sudah berjalan dengan baik sesuai yang di tentukan dilihat dari kebijakan dan prosedur yang telah dibuat dalam perusahaan menyangkut penjualan kredit untuk mencegah atau mendeteksi terjadinya sesuatu yang tidak beres atau penyimpangan.

Penilaian resiko yang dilakukan sudah berjalan dengan baik, perusahaan ini telah melakukan upaya-upaya untuk mengantisipasi kemungkinan adanya risiko yang diakibatkan oleh karyawan itu sendiri dan risiko dari konsumen yang memiliki kaitan dengan penjualan kredit. Misalnya pada Penilaian resiko 5C (Charcter, Capital, Capacity, Condition dan Collateral) sebagai alat bantu dalam menganalisa dan menilai kelayakan Calon Konsumen (CK), Memberikan gambaran mengenai keadaan CK sehingga dapat digunakan dalam pengambilan keputusan kredit serta menjunjung tingga atas kehati-hatian (prudent) dalam proses persetujuan kredit.

Pemantauan atau pengawasan pada PT Bussan Auto Finance Makassar 2 berjalan dengan baik, karena masing-masing bagian sudah menyadari tugas, aktivitas dan tanggungjawab dalam bagiannya masingmasing. Selain itu, kepala cabang juga selalu mengawasi bawahnnya dan memberikan arahannya yang bertanggungjawab dalam hal ini atau dalam tugasnya.

Informasi dan komunikasi terhadap penjualan kredit ini sudah berjalan dengan baik dan efektif, karena informasi ini memiliki akses yang mudah dan lebih cepat dalam memperoleh data dan menghubungi pihak yang berkaitan dengan penjualan kredit. Informasi ini diperoleh oleh pihak penagihan menjadi bahan untuk mengecek apakah konsumen telah melaksanakan perjanjian yang telah di buat sebelumnya dengan perusahaan. Selain itu, bagian penagihan (ARO) dan bagian penjualan (CMO) tetap berkomunikasi satu sama lain untuk memastikan berjalannya penjualan kredit berdasarkan data yang di terima oleh masing-masing bagian. 
Secara umum perbandingan pengendalian internal pada PT Bussan Auto Finance Makassar 2 dengan teori dapat dilihat pada tabel, yaitu sebagai berikut :

Tabel 4.1

Perbandingan unsur-unsur pengendalian internal berdasarkan kerangka COSO dengan PT.Bussan Auto Finance Cabang Makassar 2

\begin{tabular}{|c|c|c|}
\hline $\begin{array}{c}\text { Sistem } \\
\text { pengendalian } \\
\text { internal } \\
\text { berdasarkan } \\
\text { kerangka COSO }\end{array}$ & $\begin{array}{l}\text { Sistem pengendalian internal penjualan } \\
\text { kredit pada PT BUSSAN AUTO } \\
\text { FINANCE MAKASSAR } 2\end{array}$ & Kesimpulan \\
\hline $\begin{array}{l}\text { Lingkungan } \\
\text { Pengendalian }\end{array}$ & $\begin{array}{l}\text { Lingkungan pengendalian pada PT } \\
\text { Bussan Auto Finance Makassar } 2 \text { yaitu } \\
\text { perusahaan dan mam melakukan } \\
\text { pengendalian terhadap penjualan kredit } \\
\text { dengan adanya visi misi perusahaan } \\
\text { yaitu visi, menjadi perusahaan } \\
\text { pembiayaan terkemuka dan terpercaya } \\
\text { bagi pelanggan mitra usaha dan } \\
\text { msyarakat dan misi memberikan layanan } \\
\text { solusi keuangan terbaik untuk } \\
\text { meningkatkan kesejahteraan hidup } \\
\text { masyarakat. hal ini ditandai diadakannya } \\
\text { perusahaan yang mencakup sikap para } \\
\text { manajemen dan karyawan terhadap } \\
\text { pentingnya pengendalian yang ada di } \\
\text { organisasi tersebut diantaranya adalah } \\
\text { Nilai Integritas dan etika, Struktur } \\
\text { Organisasi, Dewan direksi dan komite } \\
\text { audit, Komitmen teradap kompetensi, } \\
\text { Pendelegasian Wewenang dan } \\
\text { Tanggung Jawab, Filosofi dan Gaay } \\
\text { Operasi, Kebijakan dan praktek sumber } \\
\text { daya manusia. }\end{array}$ & $\begin{array}{l}\text { Sudah } \\
\text { sesuai }\end{array}$ \\
\hline $\begin{array}{l}\text { Aktivitas } \\
\text { Pengendalian }\end{array}$ & $\begin{array}{l}\text { Aktivitas pengendalian pada PT Bussan } \\
\text { Auto Finance Makassar } 2 \text { sudah berjalan } \\
\text { dengan baik dengan adanya prosedur } \\
\text { yang terkait dengan transaksi penjualan } \\
\text { kredit. Prosedur ini dimaksudkan adalah } \\
\text { aktivitas-aktivitas dalam menjalankan } \\
\text { penjualan kredit (aktivitas persetujuan } \\
\text { kerja, aktivitas tanggung jawab, Aktivitas } \\
\text { pemisahan tugas, Aktivitas } \\
\text { Pendokumentasian, Rekonsiliasi) yang } \\
\text { menunjang terlaksananya tujuan dalam } \\
\text { pelaksanaan penjualan kredit. }\end{array}$ & $\begin{array}{l}\text { Sudah } \\
\text { sesuai }\end{array}$ \\
\hline Penilaian Resiko & $\begin{array}{l}\text { Penilaian risiko pada PT Bussan Auto } \\
\text { Finance Makassar } 2 \text { dilakukan sudah }\end{array}$ & $\begin{array}{l}\text { Sudah } \\
\text { sesuai }\end{array}$ \\
\hline
\end{tabular}




\begin{tabular}{|c|c|c|}
\hline & $\begin{array}{l}\text { berjalan dengan baik, perusahaan ini } \\
\text { telah melakukan upaya untuk } \\
\text { mengantisipasi kemungkinan adanya } \\
\text { risiko yang diakibatkan oleh karyawan itu } \\
\text { sendiri dan risiko dari konsumen yang } \\
\text { memiliki kaitan dengan penjualan kredit. } \\
\text { Misalnya pada Penilaian resiko 5C } \\
\text { (Charcter, Capital, Capacity, Condition } \\
\text { dan Collateral) sebagai alat bantu dalam } \\
\text { menganalisa dan menilai kelayakan } \\
\text { Calon Konsumen (CK), Memberikan } \\
\text { gambaran mengenai keadaan CK } \\
\text { sehingga dapat digunakan dalam } \\
\text { pengambilan keputusan kredit serta } \\
\text { menjunjung tingga atas kehati-hatian } \\
\text { (prudent) dalam proses persetujuan } \\
\text { kredit. }\end{array}$ & \\
\hline $\begin{array}{l}\text { Pemantauan atau } \\
\text { Monitoring }\end{array}$ & $\begin{array}{l}\text { Pemantauan atau monitoring pada PT } \\
\text { Bussan Auto Finance Makassar } 2 \text { sudah } \\
\text { berjalan sesuai tugasnya masing-masing. } \\
\text { Setiap bidang bertanggungjawab atas } \\
\text { tugas yang diberikan oleh perusahaan, } \\
\text { terutama bagian penagihan (ARO) yang } \\
\text { dituntut untuk bekerja secara maksimal } \\
\text { untuk mencegah terjadinya piutang tak } \\
\text { tertagih. Dan kepala cabang akan } \\
\text { mengawasi kinerja masing-masing } \\
\text { karyawan dan mengevaluasi untuk } \\
\text { menilai kinerja dan tingkat masing- } \\
\text { masing prestasi karyawan yang } \\
\text { bersangkutan, dengan hal ini, berkaitan } \\
\text { dengan pembelian promosi dan } \\
\text { mendapat insentif. }\end{array}$ & $\begin{array}{l}\text { Sudah } \\
\text { sesuai }\end{array}$ \\
\hline $\begin{array}{l}\text { Informasi } \\
\text { komunikasi }\end{array}$ & $\begin{array}{l}\text { Pada PT Bussan Auto Finance Makassar } \\
2 \text {, informasi dan komunikasi terhadap } \\
\text { penjualan kredit sudah berjalan dengan } \\
\text { baik dan efektif. Informasi yang diperoleh } \\
\text { dari konsumen sangatlah penting } \\
\text { kemudian akan dikomunikasikan oleh } \\
\text { bagian penjualan dan penagihan dalam } \\
\text { menjalankan tugasnya masing-masing. } \\
\text { Memiliki akses yang mudah dan lebih } \\
\text { cepat dalam memperoleh data dan } \\
\text { menghubungi pihak yang berkaitan } \\
\text { dengan penjualan kredit. Informasi data } \\
\text { masing-masing magian yang } \\
\text { bersangkutan melakukan komunikasi } \\
\text { mengenai penjualan kredit, dan } \\
\text { mencocokkan data mereka sehingga } \\
\text { tidak ada data yang dimanipulasi } \\
\text { didalamnya. }\end{array}$ & $\begin{array}{l}\text { Sudah } \\
\text { sesuai }\end{array}$ \\
\hline
\end{tabular}




\section{KESIMPULAN}

\section{Kesimpulan}

Berdasarkan hasil penelitian, maka dapat ditarik kesimpulan bahwa sistem pengendalian internal penjualan kredit berdasarkan kerangka Coso pada PT Bussan Auto Finance Makassar 2 sudah sesuai dengan kerangka adopsi Coso dengan tercapainya suatu tujuan organisasi yang melalui unsurunsur di dalamnya yang mencakup lingkungan pengendalian, aktivitas pengendalian, penilaian resiko, pemantauan dan monitoring dan informasi dan komunikasi yang sudah sesuai di perusahaan.

\section{Saran}

Saran yang di berikan oleh penulis adalah sistem pengendalian interni penjualan kredit berdasarkan kerangka Coso di PT Bussan Auto Finance Makassar 2 tetap dipertahankan penerapannya sesuai Kerangka Coso yang telah di atur oleh Atasan. Dengan komponen pengendalian intern menurut standar Coso yang meliputi lingkungan pengendalian, aktivitas pengendalian, penilaian resiko, pemantauan dan monitoring dan informasi dan komunikasi.

\section{DAFTAR PUSTAKA}

Harvarindo, 2009. Pengendalian Intern; Financial Report Audit. Jakarta; Mulyadi, 2016. Sistem Akuntansi, Edisi Empat. Jakarta; Salemba Empat. Sukrisno Agoes, 2017. Auditing Buku 1, Edisi Lima. Jakarta; Salemba Empat.

Harby Antonius. 2019. Evaluasi Sistem Pengendalian Intern Terhadap Penjualan Kredit Pada Pt. Varia Usaha Beton Makassar.Makassar

Lina Mariana,2020, Evaluasi Tingkat Kepatuhan Wajib Pajak Umkm Di Kpp Pratama Makassar Barat, Invoice: Jurnal Ekonomi Akuntansi Vol 2 No 1 , hal 38-52

https://salamadian.com/pengertian-evaluasi/dan

https://www.pelajaran.co.id/2017/28/pengertian-sistem-menurut-para-

$\underline{\text { ahli.html (Online) diakses pada tanggal } 09 \text { Maret } 2020}$

https://materibelajar.co.id/pengertian-pengendalian-intern-menurut-para-ahli/ (Online) diakses pada tanggal 12 Maret 2020 
http://sistem-akuntansi1000.blogspot.com/2012/09/sistem-akuntansi-

penjualan-kredit-retur.html?m=1dan

https://eprints.polsri.ac.id/4795/3/BAB\%201I/pdf (Online) diakses pada tanggal 27 Maret 2020 